\title{
Long-term changes in the mean trophic level of Central Chile fishery landings*
}

\author{
HUGO ARANCIBIA ${ }^{1}$ and SERGIO NEIRA ${ }^{2}$ \\ ${ }^{1}$ Departamento de Oceanografía, Universidad de Concepción, PO Box 160-C, Concepción, Chile. \\ E-mail: harancib@udec.cl \\ ${ }^{2}$ Zoology Department, University of Cape Town, Rondebosh 7701, Cape Town, Republic of South Africa.
}

\begin{abstract}
SUMMARY: We explore long-term changes in the mean trophic level (TLm) of Central Chile fishery landings, using a 21 years data series (1979-1999) of official landings (Chilean Fisheries Service) of 16 species that comprise about $95 \%$ of total landing, and their corresponding trophic level estimated using gut content analysis and a trophic model of the Central Chile marine ecosystem. Because total landings off Central Chile have been strongly influenced by landings of horse mackerel (Trachurus symmetricus), which is a trans-zonal fishery resource (sensu FAO), and the periodic occurrence of El Niño Southern Oscillation (ENSO) events in the study area, we explore changes in TLm both excluding landings of horse mackerel and excluding landings in ENSO years. When landings of horse mackerel are excluded, a significant decline in TLm is found, at a rate of 0.175 per decade, which is higher than the global rate of 0.10 estimated by Pauly et al. (1998). Fisheries in Central Chile seem to have been fishing down the food web as the result of fishery-induced changes, since ENSO events do not seem to have induced a significant effect in this trend. Therefore, we suggest that landings of horse mackerel have masked the fishing down the food web process in local fisheries.
\end{abstract}

Key words: mean trophic level, fishery landings, Central Chile.

RESUMEN: CAMBIOS DE LARGO PLAZO EN EL NIVEL TRÓFICO PROMEDIO DE LOS DESEMBARQUES PESQUEROS EN CHILE CENTRAL. - Se explora cambios de largo plazo en el nivel trófico promedio (NTp) de los desembarques pesqueros en Chile central, utilizando una serie de tiempo de 21 años (1979-1999) de desembarques (Estadísticas Oficiales Servicio Nacional de Pesca) de 16 especies, que dan cuenta de un $95 \%$ del desembarque total, y su nivel trófico correspondiente estimado mediante análisis de contenido estomacal y un modelo trófico del ecosistema marino frente a Chile central. Debido a la marcada influencia del desembarque de jurel (Trachurus symmetricus), recurso pesquero trans-zonal (sensu FAO), en el desembarque total en Chile central y la ocurrencia periódica de eventos El Niño Oscilación del Sur (ENOS), se explora los cambios en NTp excluyendo los desembarques de jurel y el desembarque en años ENOS. Al excluir el efecto del desembarque de jurel se observa una disminución significativa de $N T p$ a una tasa de 0.175 por década, lo que es mayor que la tasa global de 0.10 estimada por Pauly et al. (1998). Esta tendencia se debería a cambios inducidos principalmente por la pesquería ya que ENOS no habría afectado significativamente. Por lo tanto, sugerimos que los altos desembarques de jurel habrían enmascarado el proceso de "fishing down the food webs" en Chile central, el que se habría producido en pesquerías más locales.

Palabras clave: nivel trófico promedio, desembarques pesqueros, Chile central.

\section{INTRODUCTION}

The mean trophic level of fishery landings (TLm) has been proposed by Pauly et al. (1998) as

*Received September 18, 2003. Accepted September 29, 2004. an index of the impact of fishing. On a global scale, $T L m$ has showed a decreasing trend for the last 45 years as a result of a gradual transition in landings from piscivorous, long-lived and high trophic level species to short-lived and low trophic level species (i.e. planktivorous pelagic fish and crustaceans). 
This phenomenon is called 'fishing down the food webs' (FDFW) and, in an initial stage the transition in target species produces an increase in landings, followed in a more advanced stage by a decrease in landings that could reflect fishery-induced changes at the community and ecosystem levels (Pauly et al., 1998).

Although FDFW constitutes a controversial issue, even the most reluctant scientists agree that FDFW could be one of the explanations for changes in fish populations on global scales (Caddy et al., 1998; Caddy and Garibaldi, 2000). However, considering the complexity and high regional variability in world fisheries (Botsford et al., 1997), analyses are needed to test whether FDFW is also occurring in more local fisheries.

For the South Pacific Ocean (FAO areas 81 and 87), Pauly et al. (1998) report wide amplitude fluctuations in $T L_{m}$, with landings continuing to increase as $T L_{m}$ declined in recent years. Both features seem to be an exception to FDFW. A possible explanation is found in the Peruvian anchoveta fishery collapse and the later development of an important offshore fishery based on horse mackerel (Trachurus symmetricus), which is a migratory species at a high trophic level. Therefore, high landings of horse mackerel could have masked changes in more local fisheries in recent years (Pauly et al., 1998).

The Humboldt Current System off Central Chile is a typical eastern boundary current system sustaining one of the most productive fisheries worldwide (FAO, 1995). By the late 1970s, the horse mackerel had become the most important fishery resource of Central Chile thanks to the development and later westward expansion of an important offshore fishery, mainly composed of an industrial purse-seine fleet. Consequently, landings of horse mackerel have influenced total landings in Central Chile in recent decades (Fig. 1). Although the ecosystem impacts of fishing on fish assemblages off Central Chile are poorly understood, evidence indicates that the most important fishery resources seem to have reached their maximum sustainable level, while others show clear signs of overexploitation (Cubillos $e t$ al., 1999; Quiñones et al., 2003).

It is acknowledged that El Niño Southern Oscillation (ENSO) is responsible for most of the interannual variability in the whole Eastern Pacific Ocean basin (Strub et al., 1998). In Central Chile, ENSO induces changes in marine populations, especially fishes inhabiting the pelagic domain (Yáñez et al., 1992; Arcos et al., 2001), but also benthic

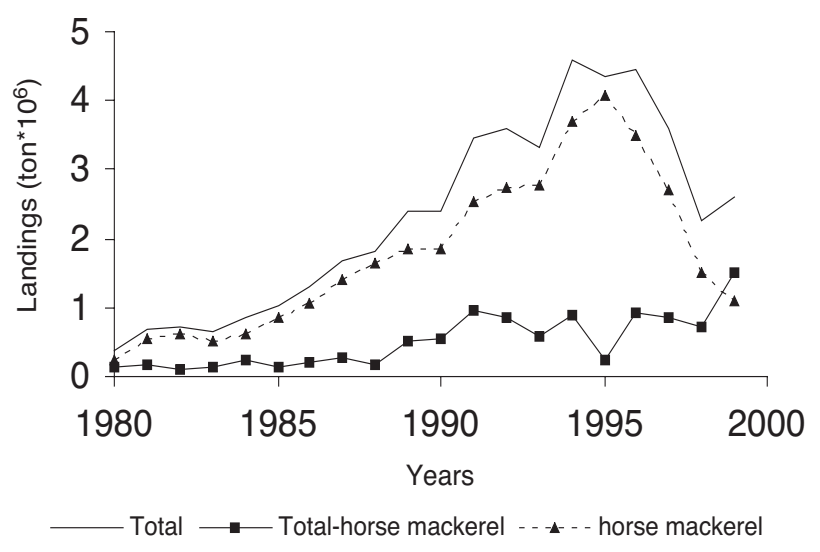

FIG. 1. - Total landings, total landings without including horse mackerel, and horse mackerel landings in Central Chile (19791999).

species (Gutiérrez et al., 2000). This is important because landings off Central Chile are dominated mostly by pelagic fish species (Neira et al., 2004).

Consequently, the objectives of the present study are: i) to examine long-term changes in $T L_{m}$ of fishery landings from Central Chile, ii) to determine whether the long term trend of $T L_{m}$ in Central Chile has been masked by landings of horse mackerel, and iii) to determine whether changes in $T L_{m}$ are influenced by ENSO events.

\section{MATERIAL AND METHODS}

The study area (Fig. 2) represents the marine zone off Central Chile $\left(33^{\circ} \mathrm{S}\right.$ to $\left.39^{\circ} \mathrm{S}\right)$, which was defined taking into account both fishery management units and the distribution patterns of the most important fishing fleets. The study area is also a biogeographic unit defined by the following oceanographic and topographic features: highly seasonal coastal upwelling events (Arcos and Navarro, 1986); high turbulence during summer due to southwesterly winds, but also during winter due to weather fronts crossing the region from the west; and high offshore transport levels during summer (Ahumada, 1989; Strub et al., 1998).

Landing data by species (in tonnes wet weight) were obtained from the Chilean Fisheries Service Statistics Yearbooks (1979-1999; www.sernapesca.cl). Landings for the 16 selected species (Table 1) correspond to the sum of their landings from 33 to $39^{\circ} \mathrm{S}$. The selected species comprise about $95 \%$ of the total landings in Central Chile.

The trophic level for species $i\left(T L_{i}\right)$ was estimated using the available information on gut content 


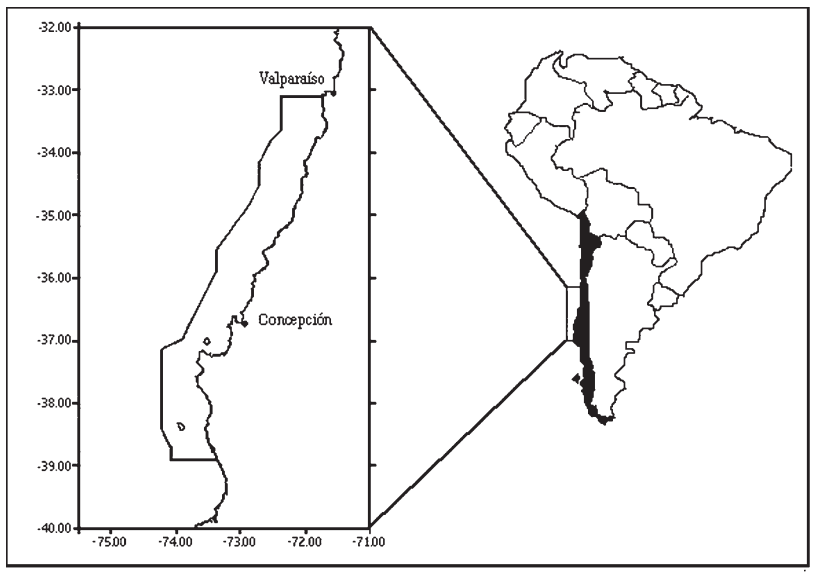

FIG. 2. - Study area. Marine zone off Central Chile $\left(33^{\circ} \mathrm{S}-39^{\circ} \mathrm{S}\right)$.

analysis derived from surveys designed to obtain biomass estimates and diet for the target and bycatch species in fisheries off Central Chile and the Ecopath with Ecosim software version 5.0 (EwE; Christensen and Pauly, 1992; Walters et al., 1997). Values of $T L_{i}$ for mackerel, elephant fish and snoek were gathered from FishBase (Froese and Pauly, 2002), while $T L_{i}$ for golden conger-eel and red conger-eel were assumed to be similar to $T L_{i}$ estimated for black conger-eel (G. maculatus) using trophic models (see Table 1).

Following Pauly et al. (1998), estimates of the mean weighted trophic level of the catch $\left(T L_{m}\right)$ for each year of the time series were calculated as:

$$
T L_{m}=\sum_{i=1}^{n} T L_{i} *\left(\frac{Y_{i}}{Y_{T}}\right)
$$

where $T L_{i}$ is the trophic level of species $i ; Y_{i}$ is the landing of species $i$ in a given year; $Y_{T}$ is the total landing of all species in the same year, and $n$ is the number of years.

To account for the effect of horse mackerel on the long-term trend of $T L_{m}$, two analyses were carried out. First, we calculated $T L_{m}$ considering all selected species. Then, we recalculated $T L_{m}$ excluding landings of horse mackerel.

To account for ENSO-induced changes in $T L_{m}$, we recalculated $T L_{m}$ excluding landings in years with ENSO events. Following the National Oceanographic and Atmospheric Administration (NOAA) definition of ENSO years (www.cdc.noaa.gov/map/ clim/sst_olr/el_nino_anim.shtml), 1982-1983, 19911992, 1994-1995 and 1997-1998 were considered as ENSO warm events, while 1984, 1988-1989, 19951996 and 1998-1999 were considered as ENSO cold events.
Table 1. - List of the species included in this study and their corresponding trophic level. (a): estimated in this study using gut content analysis (Lillo et al., 1993; Arancibia, 1992; Arrizaga, 1983; Arrizaga et al., 1993; Cordova et al., 1999) and the Ecopath with Ecosim software; (b): assigned assuming these species have a diet composition similar to G. maculatus, which was estimated in this study; (c): FishBase (Froese and Pauly, 2002).

\begin{tabular}{llc}
\hline Common name & Scientific name & Trophic Level \\
\hline Pacific sandperch & Prolatilus jugularis & $3,77^{\mathrm{a}}$ \\
cardinal fish & Epigonus crassicaudus & $3,72^{\mathrm{a}}$ \\
horse mackerel & Trachurus symmetricus & $3,72^{\mathrm{a}}$ \\
snoek & Thyrsites atun & $3,70^{\mathrm{c}}$ \\
common hake & Merluccius gayi & $3,49^{\mathrm{a}}$ \\
red conger-eel & Genypterus chilensis & $3,43^{\mathrm{b}}$ \\
golden conger-eel & Genypterus blacodes & $3,43^{\mathrm{b}}$ \\
black conger-eel & Genypterus maculatus & $3,43^{\mathrm{a}}$ \\
mackerel & Scomber japonicus & $3,30^{\mathrm{c}}$ \\
elephant fish & Callorhynchus callorhynchus & $3,20^{\mathrm{c}}$ \\
skates & Raja spp. & $3,00^{\mathrm{a}}$ \\
anchovy & Engraulis ringens & $2,02^{\mathrm{a}}$ \\
sardine & Sardinops sagax & $2,02^{\mathrm{a}}$ \\
common sardine & Strangomera bentincki & $2,02^{\mathrm{a}}$ \\
red squat lobster & Pleuroncodes monodon & $2,00^{\mathrm{a}}$ \\
yellow squat lobster & Cervimunida johni & $2,00^{\mathrm{a}}$ \\
& & \\
\hline
\end{tabular}

Spearman's rank correlation (rs) was used to establish a significant relationship between $T L_{m}$ and year and $T L_{m}$ and landings.

\section{RESULTS}

The maximum $T L_{i}$ (near $T L=4$ ) was found in Pacific sandperch (Prolatilus jugularis), while the lowest value (near $T L=2$ ) was shared by planktivorous fish (anchovy, sardine and common sardine) and detritivorous benthic crustaceans (red squat lobster and yellow squat lobster) (Table 1).

Changes in $T L_{m}$ in Central Chile are shown in Figure 3. $T L_{m}$ of all landings did not show a significant decreasing trend ( $r s=-0.15, p=0.493$ ) (Fig. 3a). The greatest $T L_{m}$ value for the time series was found for $1988\left(T L_{m}=3.58\right)$. The lowest values are in the first $\left(1979 ; T L_{m}=3.23\right)$ and the last year of the time series (1999; $\left.T L_{m}=2.67\right)$, and are related mostly to the low horse mackerel landings in those years (Fig. 1). In fact, at the beginning of the time series, the horse mackerel fishery was hardly exploited, while at the end it was heavily over-exploited (Quiñones et al., 2003). However, when landings of horse mackerel were excluded, $T L_{m}$ showed a significant decline (rs=-0.70, p<0.001) (Fig. 3b). ENSO events did not seem to have greatly affected the long-term trend of $T L m$. In fact, when landings in ENSO years are eliminated, the correlation improves ( $\mathrm{rs}=-0.93, \mathrm{p}<0.001$ ) (Fig. 3c). Therefore, a significant negative correlation 

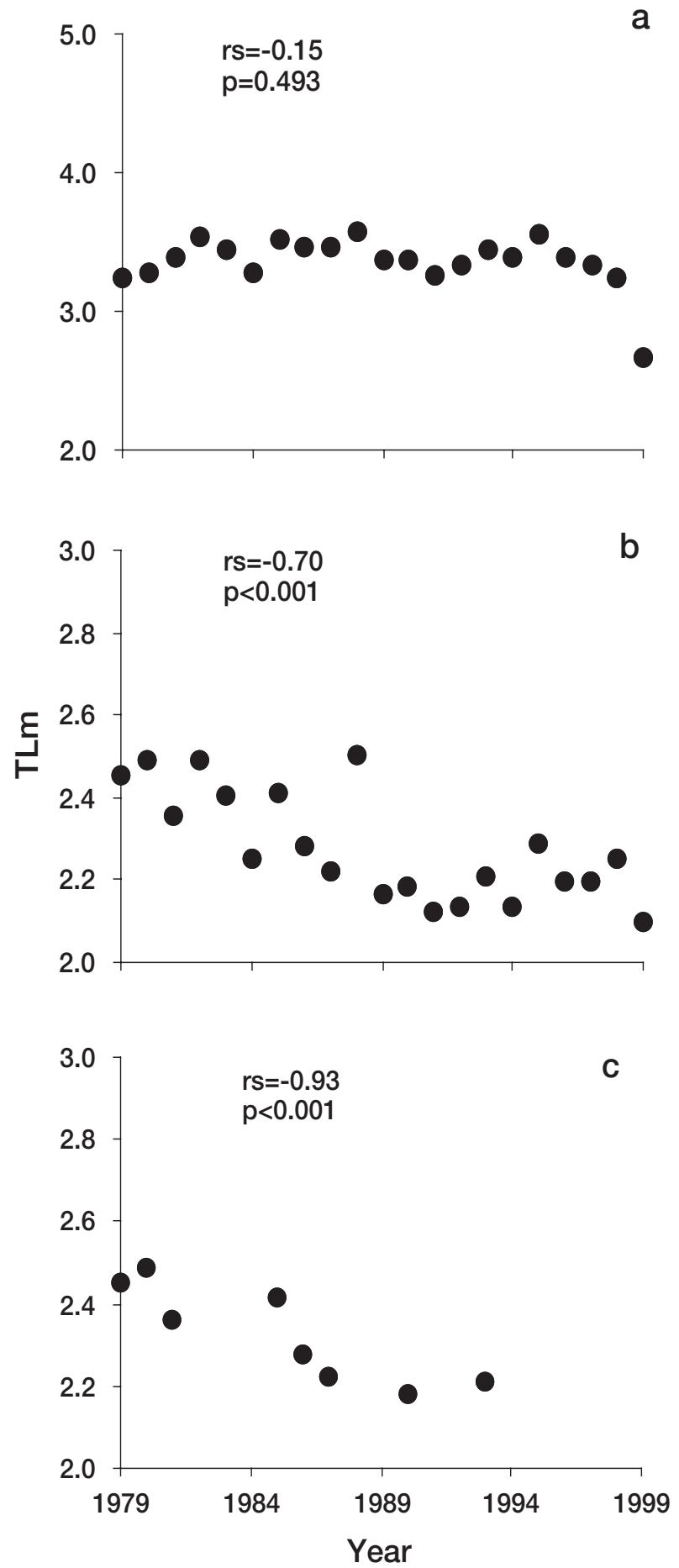

FIG. 3. - Mean trophic level of fishery landings (TLm) in Central Chile $\left(33^{\circ} \mathrm{S}-39^{\circ} \mathrm{S}\right)$. a) Total landings; b) excluding landings of horse mackerel; c) excluding landings of horse mackerel and landings in years affected by El Niño Southern Oscillation.

between $T L_{m}$ and time is found. This could reveal the effect of FDFW once the effects of horse mackerel and ENSO are removed.

There was no significant relationship between total landings and corresponding mean trophic levels ( $r s=0.03 ; p=0.902$; Fig. 4a). Landings
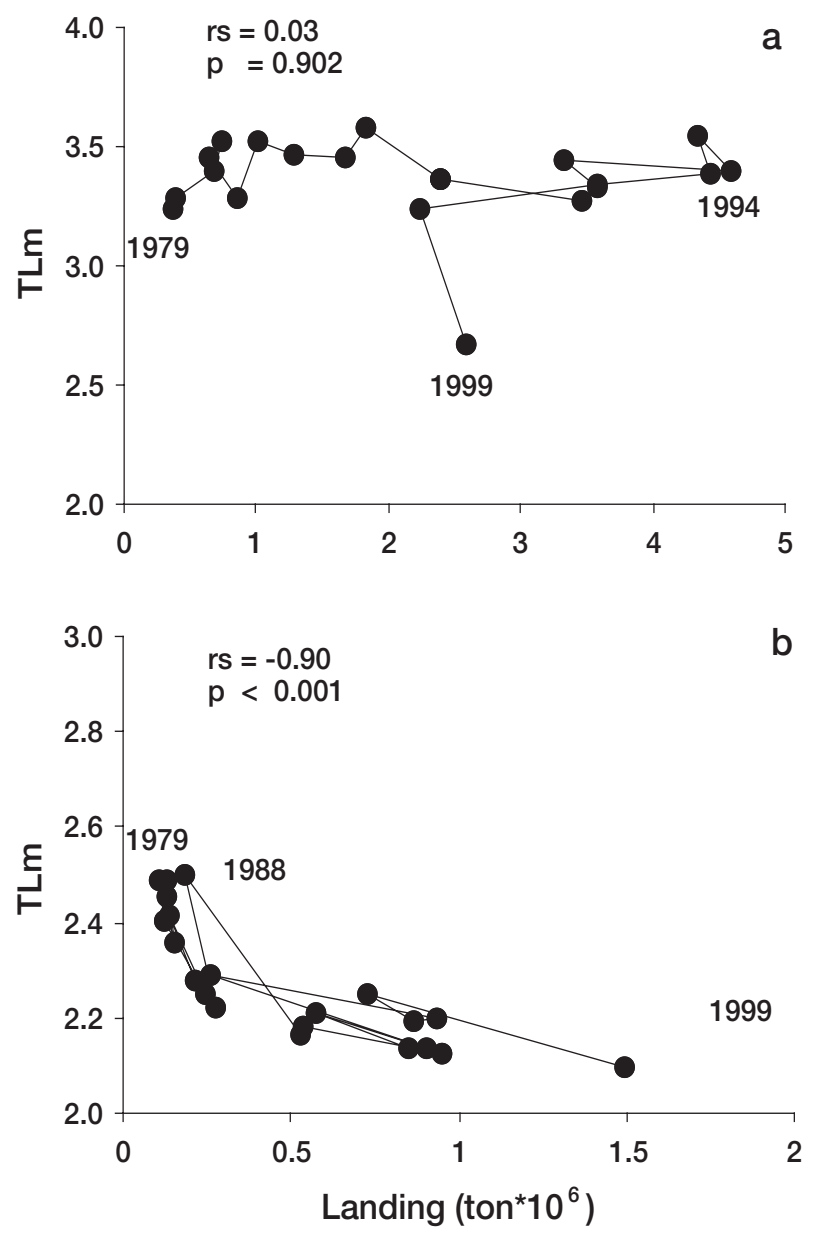

FIG. 4. - Trophic level of fishery versus landings in Central Chile $\left(33^{\circ} \mathrm{S}-39^{\circ} \mathrm{S} 9\right.$. a) Total landings; b) excluding landings of horse mackerel.

increased until 1994 without great changes in $T L_{m}$. At this point, the relationship tends to revert due to a decline in total landings. When horse mackerel landings are excluded from the analysis (Fig. 4b), a clear inverse relationship between $T L_{m}$ and landings is observed ( $r=0.90 ; p<0.001)$. In this case, landings are still increasing while mean trophic level of the fishery decreases. The increase of $T L_{m}$ in year 1988 is mainly related to the dramatic drop in landings of the sardine $(S$. sagax), a species of a low trophic level, from more than 100 thousand tonnes in 1997 to about 50 thousand tonnes in 1998.

\section{DISCUSSION}

There are some potential limitations in our analysis. The number of species included in this study is small when compared to similar published analyses (e.g. Pauly et al., 1998; Pinnegard et al., 2003). 
However, the selected species comprise $95 \%$ of landings and therefore we can argue that landings of those species not included in the present analysis are almost insignificant. Therefore, we consider that the potential impact of not including more species on the calculations and observed trends is weak.

We consider that the estimation of $T L_{i}$ could be the factor that incorporates the highest uncertainty into our analysis. $T L_{i}$ values were estimated using quantitative information of gut contents obtained from research surveys designed to estimate stock size for the main fishery resources in Central Chile. Unfortunately, gut content analyses for the most of the groups in the study area have been sporadic and short-term. Consequently, it was not possible to estimate the $T L_{i}$ variance. The assumption of assigning a single trophic level to a species is problematic, as pointed out by Caddy et al. (1998), since ontogenetic change in diet, and consequently in trophic level, is common in marine species. However, considering that most species feed at lower trophic levels when they are smaller, and fishing pressure usually reduces the mean size of fish, the effect can be considered as conservative (Pauly et al., 1998; Pinnegard et al., 2003).

We acknowledge that alternative and independent methods, such as using stable isotopes of nitrogen (Post, 2002), are available to establish $T L$ in aquatic organisms. However, although the estimation of TL using gut contents can induce bias, some studies have shown a significant correlation between $T L s$ estimated using gut content and those estimated using radioisotopes (Kline and Pauly, 1998; Pinnegard et al., 2003).

Another factor that could have biased the observed trend in $T L_{m}$ is the relatively low trophic level of small pelagic fish in Central Chile $(\mathrm{TL}=2.02)$ compared to $T L \mathrm{~s}$ of similar species in comparative ecosystems (Jarre-Teichmann et al., 1998). The low $T L$ of small pelagic fish in Central Chile is explained by the fact that, in this system, unlike other upwelling systems, these species seem to feed almost exclusively on phytoplankton (Arrizaga, 1983; Arrizaga et al., 1993). However, when $T L_{m}$ is recalculated under the assumption that small pelagic fish feed $50 \%$ on phytoplankton and $50 \%$ on zooplankton (i.e. $\mathrm{TL}=2.5$ ), a significant decreasing trend in $T L_{m}$ is still observed (rs=-0.65; $\mathrm{p}=0.001$ ).

Since fishing activity in Central Chile started before the period covered by our 21-years data series, it is possible that populations of top predators that are not present in landings today could have been overexploited before 1979. In fact, in this area both sperm whale (Physeter catodon) and sea lion (Otaria flavescens) used to be hunted (AguayoLobo et al., 1998). However, the hunting activities of both species were stopped after their populations had been severely depleted. Therefore, our study can be viewed as summarising the trends in $T L$ of the catches of fish off Central Chile (because harvesting of mammals in early years is excluded), with the exception of swordfish (Xiphias gladius). This species sustained an important inshore artisan fishery from 1952 to 1986 (Barbieri et al., 1998). After that, landings of swordfish have corresponded mostly to individuals captured by an industrial fleet of long-liners operating beyond the Chilean Exclusive Economic Zone (i.e. offshore of 200 nautical miles).

When horse mackerel landings are excluded from the analysis, it is observed that, over time, the longterm $T L_{m}$ shows a decreasing trend, in accordance with what is predicted by the hypothesis of FDFW. Fisheries landings in Central Chile are highly dependent on fish species, especially small-sized pelagic fishes such as common sardine and anchovy, which are located at low trophic levels (Neira et al., 2004).

The increasing importance of small pelagic fish in the Central Chile fishery landings could be explained by a change in fishery preferences (due to the lack of more valuable species), high fishing mortality and good recruitment (SSP, 2001; Quiñones et al., 2003). In addition, both abundance and availability of common sardine and anchovy are also related to interannual and long-term changes in the environment (Yáñez et al., 1992). Fishing removal of both common sardine and anchovy is likely to impact the whole food web, since wasp waist control exerted by small pelagic fishes is hypothesised to be characteristic feature in upwelling ecosystems (Cury et al., 2000).

In conclusion, our analysis confirms that landings of horse mackerel have masked a FDFW process in inshore fisheries off Central Chile, as suggested by Pauly et al. (1998). In addition, we suggest that fisheries in Central Chile have been fishing down the food web as a result of fishery-induced changes rather than environmental changes associated with ENSO events. In Central Chile, $T L_{m}$ has declined at a rate of 0.175 levels per decade, from 2.45 in 1979 to 2.10 in 1999 , which is higher than the global rate of 0.10 levels per decade estimated by Pauly et al. (1998). This trend is also higher than the decreasing trend estimated, for instance, for the 
Gulf of Thailand, an ecosystem in which fisheries resources have been depleted by human activities (Christensen, 1998).

\section{ACKNOWLEDGEMENTS}

We are grateful to the EU INCO-DC Concerted Action Project "Placing fisheries in their ecosystem context", through which funding was granted for both a workshop in Sao Paulo, Brazil (December 1998) and a conference in the Galapagos Islands (December 2000). We also thank two anonymous referees for their comments on an earlier version of this paper.

\section{REFERENCES}

Aguayo-Lobo A., D. Torres and J. Acevedo. - 1998. Los mamíferos de Chile: I Cetacea. Ser. Cient. INACH, 48: 19-159.

Ahumada, R. - 1989. Producción y destino de la biomasa fitoplanctónica en un sistema de bahías en Chile central: una hipótesis. Biol. Pesq. (Chile), 18: 53-66.

Arancibia, H. - 1992. Análisis de la alimentación de merluza común (Merluccius gayi) en el largo plazo y su impacto en prereclutas. Informe Final Proyecto Fondecyt 24/92, 52 p.

Arcos, D.F., L.A. Cubillos and S.P. Núnez. - 2001. The jack mackerel fishery and El Nino 1997-98 effects off Chile. Prog. Oceanog., 49(1-4): 597-617.

Arcos, D. and N. Navarro. - 1986. Análisis de un índice de surgencia para la zona de Talcahuano, Chile (Lat. $37^{\circ} \mathrm{S}$ ). Inv. Pesq. (Chile), 33: 91-98.

Arrizaga, M.A. - 1983. Seasonal food variation in the common sardine Clupea (Strangomera) bentincki Norman, 1936 (Pisces, Clupeidae) in Bio-Bio Region, Chile. Bol. Soc. Biol. Concepción (Chile), 54: 7-26.

Arrizaga, A., M. Fuentealba, C. Espinoza, Chong, J. and C. Oyarzún. - 1993. Trophic habits of two pelagic fish species: Strangomera bentincki (Norman, 1936) and Engraulis ringens (Jenyns, 1842), in the litoral of the Biobio Region, Chile. Bol. Soc. Biol. Concepción (Chile), 64: 27-35.

Barbieri. M.A., C. Canales, V. Correa, M. Donoso, A. González, B. Leiva, A. Montiel and E. Yáñez - 1998. Development and present State of the Swordfish, Xiphias Gladius, fishery in Chile. In: I. Barret, O. Sosa-Nishizaki and N. Bartoo (eds.), Biology and Fisheries of sword fish Xiphias gladius, pp. 1-10. Ensenada, Mexico.

Botsford, L. W., J. C. Castilla and C. H. Peterson. - 1997. The management of fisheries and marine ecosystems. Science, 277: 509-515.

Caddy, J. and L. Garibaldi. - 2000. Apparent changes in the trophic composition of world marine harvests: the perspective from the FAO capture database. Ocean Coast. Manag., 43: 615-655.

Caddy, J., J. Csirke, S.M. García and R.J.R. Grainer. - 1998. How pervasive is "Fishing down the food webs". Science, 282: 1839.

Christensen, V. - 1998. Fishery-induced changes in a marine ecosystem: insights from models of the Gulf of Thailand. $J$. Fish Biol., 53(Suppl. A): 128-142.

Christensen, V. and D. Pauly. - 1992. ECOPATH II. A software for balancing steady state ecosystem models and calculating network characteristics. Ecol. Model., 61: 169-185.

Córdova, J., M.A. Barbieri, H. Miranda, M. Espejo, M. Rojas, S. Núñez, J. Ortiz, V. Catasti, V. Valenzuela, M. Braun, C. Cuevas,
H. Rebolledo and G. Galindo. - 1999. Informe Final Proyecto FIP N ${ }^{\circ}$ 98-11 Evaluación hidroacústica del recurso jurel en la Zona Económica Exclusiva de Chile, 187 pp. +78 figs.

Cubillos, L. A. Sepúlveda, M. Gálvez and D. Arcos. - 1999. Situación actual de los principales recursos pesqueros de la zona centro-sur de Chile. Instituto de Investigación Pesquera, Talcahuano (Chile). Informe Técnico, 16(2): 23 p.

Cury, P., A. Bakun, R.J.M. Crawford, A. Jarre, R. Quiñones, L.J. Shannon, and H.M. Verheye. - 2000. Small pelagics in upwelling systems: patterns of interaction and structural changes in "wasp-waist" ecosystems. ICES J. Mar. Sci., 57: 145-155.

FAO. - 1995. World fishery production. Supplement of the FAO Yearbook of Fishery Statistics. Vol. 76, 35 p.

Froese R. and D. Pauly, Editors. 2002. FishBase. World Wide Web Electronic Publication. www.fishbase.org, 19 July 2002.

Gutiérrez D., V.A. Gallardo, S. Mayor, C. Neira, C. Vásquez, J. Sellanes, M. Rivas, A. Soto, F. D. Carrasco and M. Baltasar. 2000. Effects of dissolved oxygen and fresh organic matter on the bioturbation potential of macrofauna in sublittoral sediments off Central Chile during the 1997/1998 El Niño. Mar. Ecol. Prog. Ser., 202: 81-99.

Jarre-Teichmann, A., L. Shannon, C. Moloney and P. Wickens. 1998. Comparing trophic flows in the Southern Benguela to those in other upwelling ecosystems. In: S. Pillar, C. Moloney, A. Payne, A. Shillington (eds.), Benguela Dynamics. S. Afr. J. Mar. Sci., 19: 391-414.

Kline, T. and D. Pauly. - 1998. Cross-validation of trophic level estimates from a Mass Balance model of Prince William Sound using ${ }^{15} \mathrm{~N} /{ }^{14} \mathrm{~N}$ data. In: T.J. Funk, I. Quinn, J. Heifetz, J.N. Ianelli, J.E. Powers, J.F. Scweigert, P.J. Sulluvan and C. Zhang (eds.), Fishery stock assessment models, pp. 693-702. Alaska Sea Grant College Program Report No. AK-SG-98-01, University of Alaska, Fairbanks.

Lillo, S., I. Giakoni, A. Paillamán, I. Payá, S. Mora, C. Cerda, J. Blanco and H. Arancibia. - 1993. Evaluación directa del stock de merluza común en la zona centro-sur. Informe Final del Proyecto FIP-IT/93-03, 121 pp. + 62 figs.

Neira, S., H. Arancibia and L. Cubillos. 2004. Comparative analysis of trophic structure of commercial fishery species off central Chile in 1992 and 1998. Ecol. Model., 172: 233-248.

Pauly, D., V. Christensen, J.P.T. Dalsgaard, R. Froese and F. Torres. - 1998. Fishing down marine food webs. Science, 279: 860-863.

Pinnegard, J. K., N.V. Polunin and F. Badalamenti. - 2003. Long-term changes in the trophic level of western Mediterranean fishery and aquaculture landings. Can. J. Fish. Aquat. Sci., 60: 222-235.

Post, D.M. - 2002. Using stable isotopes to estimate trophic position: models, methods, and assumptions. Ecology, 83:703-718.

Quiñones, R. A., Barriga, O., Dresdner, J., Arancibia, H., Aliaga, B., Chávez, C., Henríquez, G., Navarrete, I., Palma, C., Salgado, H. and N. González. - 2003. Análisis económico, social y biológico de la crisis pesquera de la VIII Región (1997-2002). Informe Final Proyecto Análisis biológico, económico y social de las pesquerías de la VIII Región. Fondo Nacional de Desarrollo Regional de la Región del Bio Bio (Código BIP 20183334-0). Facultad de Ciencias Naturales y Oceanográficas, Universidad de Concepción. 566 pp. + appendices.

Strub P.T., J. Mesías, V. Montecinos, J. Ruttland and S. Salinas. 1998. Coastal ocean circulation off western south america. In: A. R. Robinson and K. H. Brink (eds.), The sea. pp. 273-312. John Wiley and Sons, Inc.

SSP. - 2001. Cuota global de captura para los recursos sardina común y anchoveta año 2002. Informe Técnico (Res. Pesq.) $\mathrm{N}^{\circ} 103,17 \mathrm{pp}$. Subsecreatría de Pesca, Gobierno de Chile.

Walters, C., V. Christensen and D. Pauly. - 1997. Structuring dynamic models of exploited ecosystems from trophic massbalance assessments. Rev. Fish Biol. Fisher., 7: 139-172.

Yáñez, E., M.A. Barbieri and L. Santillán. - 1992. Long-term environmental variability and pelagic fisheries in Talcahuano, Chile. S. Afr. J. Mar. Sci., 12: 175-188.

Scient. ed.: L. Hutchings

300 H. ARANCIBIA and S. NEIRA 